\title{
Spatial Distribution of Phytoplankton and Physico-Chemical Characteristics of Agaie-Lapai Dam, Minna, Niger State, Nigeria
}

\author{
Ojutiku, R. O. (Corresponding author) \\ Department of Water Resources, Aquaculture and Fisheries Technology \\ Federal University of Technology, Minna, Niger State, Nigeria P.M.B 065 \\ Tel: 234-803-596-4622Ｅ-mail: rasheedojutiku@yahoo.com \\ Kolo R. J. and Yakubu, M. A. \\ Department of Water Resources, Aquaculture and Fisheries Technology \\ Federal University of Technology, Minna, Niger State, Nigeria P.M.B 065
}

Received: March 16, 2016 Accepted: April 2, 2016

doi:10.5296/jbls.v7i2.9459 URL: http://dx.doi.org/10.5296/jbls.v7i2.9459

\begin{abstract}
Presence of phytoplankton displays water quality and useablity by aquatic life. Agaie-Lapai Dam located in Niger State (latitude $9^{0} 39 \mathrm{~N}$ and longitude $6^{0} 33 \mathrm{E}$ ) was constructed for irrigation purpose and also to serves as source of livelihood to fishermen living in surroundings. The objective of the present research was conducted to assess the distribution of phytoplankton and physic-chemical assessment of Agaie-Lapai Dam. Reservoir Water. Samples were collected fortnightly and analyzed for phytoplankton and physico-chemical parameters. The dissolved oxygen ranged from $3.8-5.15 \mathrm{mg} / \mathrm{l}$ and temperature from $24.6-$ $29.0^{\circ} \mathrm{C}$. A total of 14 species of 5 taxonomic groups were recorded. Bacillariophyceae was the most abundant group (44\%) followed by Chlorophyceae $(26 \%)$ while the lowest was Dinophyceae (8\%). Phytoplankton abundances in the following descending order: Bacillariophyceae $>$ Cyanophyceae $>$ Chlorophyceae $>$ Chrysophyceae $>$ Dinophyceae. The spatial analysis revealed that phytoplankton was not equally distributed in the water that enabled it to function as productive water body. The observed physico-chemical parameters fell within thus it was within the tolerable limits. It is expected that the identified species will enhance fish productivity.
\end{abstract}


Keywords: Fish production, Heavy metals in runoff water, Plankton, Reservoirs, Water quality

\section{Introduction}

Phytoplanktons are photosynthesizing organisms that are microscopic in nature which inhabit the upper layer of almost all oceans and freshwater bodies. The phytoplanktons support "primary production," Phytoplankton communities are multispecies communities, which are highly multifaceted in terms of their diversity and dynamics (Palleyiet al., 2011) and plays a key role in aquatic system.

There are two major groups of phytoplankton viz (1) diatoms, which have no means to propel themselves through the water, and (2) flagellates and dinoflagellates, which can migrate vertically in the water column in response to light. All other living organisms in water depend directly or indirectly on them for food. Phytoplankton abundance is influenced by water temperature, velocity of current, availability of nutrient and light penetration into the water (Aboweiet al, 2012).

Phytoplankton are used as suitable pollution indicators because they are simple, and capable of quantifying changes in water quality (Lee, 1999; Onyema 2003).

The distribution of phytoplankton is affected by factors such as climate, temperature, salinity, $\mathrm{pH}$, and of course, level of fertility of the water body. Productivity of a water body is influenced by the availability of the phytoplankton community. Shifts in phytoplankton community structure are mainly due to changes in environmental variables such as nutrients and other physicochemical variables which influence the distribution and abundance of plankton communities in estuaries ( Palleyiet al.,2011).

Knowledge of the plankton community of any water body is therefore, not only important in assessing its productivity but would permit a better understanding of the population dynamics and life cycles of the fish community. (Dimowo, 2011).

Maristelaet al (2003) reported that enhanced nutrient input improves plankton density and composition. Diatom and Copepoda dominance was replaced by cyanobacteria, protozoan, and rotifers as nutrient concentrations increased with the cultured period, indicating that plankton structure is affected by eutrophic conditions.

Objectives of the study are to assess the phisio-chemical parameters, heavy metal concentration and phytoplankton species diversity and abundance of Agaie-Lapai dam.

\section{Materials and Method}

\subsection{Study Area}

Agaie-lapai dam was constructed by the Niger state government at Bakajiba village (latitude $9^{0} 39 \mathrm{~N}$ and longitude $6^{0} 33 \mathrm{E}$ ), southwest of (Minna), across Jatau River. It has a reservoir capacity of 38 million cubic meters (3800 ha-m) and a dam crest length of 1,600 meters. The reservoir is shallow at the inlet about 1.64 meters and increases progressively inward to an 
average depth of 10.8 meter. The lake shore lines are swampy and inaccessible. There are three visible inlets and a large spillway on the side of the bank, the spillway and downstream are flooded seasonally during the raining season. The northern end of the dam drains into a broad swampy area and gradually narrows for small stream. Also at the southern end a small stream called chain, rivers flows directly to the dam. The three rivers that flow directly into the dam are Chain River, Jatau River from southeast and Jimada River from the northeast.

(It would have been better to include a plan map of the damand reservoir

Five sampling stations, labeled ST1, ST2, ST3, ST4, and ST5.were established on the water body. The Station one (ST1) was at the downstream close to the landing site, station two (ST2) at the upstream at the inlet from Jatau river, station three (ST3) at the inlet from Jimada river, station, four (ST4) at the middle of the dam, and station five (ST5) was at downstream located at the gauge of the dam.

Water and plankton samples were collected twice a month, for three (3) months August, September and October, 2014 in the morning $(7.00-9.00 \mathrm{am})$. Plankton net was used to collect samples from the water with a canoe, as means of transportation from one point to the other. The sample was preserved with $4 \%$ formalin, before transporting in ice chest to the laboratory.

Parameters analyzed were: Temperature, Dissolved Oxygen(DO), Biological Oxygen Demand (BOD), Chemical Oxygen Demand (COD), Conductivity, pH, Hardness, Alkalinity, Carbon dioxide, Nitrate and Phosphate. These were analyzed using the methods of APHA, 2005.

Heavy metals analyzed include Iron, Zinc, Manganese, Copper and Lead using Atomic Absorption Spectrophotometer (APHA, 2005)

Air and water temperature were measured insitu.

\section{Results and Discussion}

\subsection{Physico-Chemical Parameters}

For the physio-chemical parameters, the research shows that hardness ranges between $39.8 \mathrm{mg} / \mathrm{l}$ and $54.4 \mathrm{mg} / \mathrm{l}$. There was no significant difference between the months. This shows that hardness occurred within the standard range of 40-300mg/l (Boyd and Tucker (1992) and fell within the permissible level.

Results obtained for dissolved oxygen shows that there was no significant different between mid- August, mid-September and October ending $(\mathrm{P}>0.05)$ but There was significant different between August ending, September ending and mid-October, $(\mathrm{P} \leq 0.05)$ (Table 1)

Dissolved oxygen was within the range of $2.80 \mathrm{mg} / 1$ and $5.40 \mathrm{mg} / 1$. It was low at mid-August and mid-October. This may be due to the weather condition and temperature when the samples were taken. Production of dissolved oxygen by phytoplankton is limited by the availability of sunlight and nutrients primarily in the form of nitrogen, phosphorous and silica, (Casey 2009). Biological oxygen demand shows that there was significant different $(P \leq 0.05)$ 
between the mid-August and mid- October, August ending October ending, mid-September and September ending (Table 1).

The biological oxygen demand was between the range of $1.36 \mathrm{mg} / \mathrm{l}$ and $3.20 \mathrm{mg} / \mathrm{l}$.

Results obtained for carbon dioxide show that there was no significant different $(\mathrm{P}>0.05)$ between and within the months.

There was significant difference in carbon dioxide between the months. No significant difference $(\mathrm{P}>0.05)$ was also observed in the results of air and water temperature recorded (table 1) Air and water temperature fell within the range of $21^{\circ} \mathrm{C}$ and $29^{\circ} \mathrm{C}$ during this research. This was due to high humidity. This shows that it correspond to the normal temperature range of all tropical water bodies according to Kolo and Oladimeji (2004).

Alkalinity was within the range of $15.6 \mathrm{mg} / \mathrm{l}$ and $20 \mathrm{mg} / \mathrm{l}$. pH was between $6.54 \mathrm{mg} / \mathrm{l}$ and $6.9 \mathrm{mg} / \mathrm{l}$. This shows that the water is very much suitable for living organism.

Nitrate and phosphate was low during my research. This may be due to the unavailability of fertilizer/nutrient sources in the water. These findings vary with the finding of Kolo and Oladimeji (2004) that records higher nitrates in Shiroro Lake in rainy season.

The percentage Coefficient of Variation shows no wide variation.

The result obtained for total hardness shows no significance difference $(p>0.05)$ between the months. As shown in Table 1 There was a significant difference in the values obtained for conductivity within each month, $(\mathrm{p} \leq 0.05)$ that is, value obtained for mid-august was significantly different from august ending. Results obtained for mid-September ending and October ending were not significantly different $(\mathrm{p}>0.05)$ as shown in Table 1

\subsection{Heavy Metals.}

Results of heavy metals recorded showed no significant difference between and within months of the experiment.Manganese recorded ranged from 0.1 to $0.4 \mathrm{mg} / \mathrm{L}$ while zinc concentration recorded ranged between 0.01- 0.09 (Table 2).

Heavy metals present were manganese, zinc, copper and iron. There was no trace of lead duringthe study. They were all significantly different from each other except copper that shows no significant difference between the months.

\subsection{Distribution of Phytoplankton}

The observations revealed that that a total of 14 different species of the 5taxonomic groups were recorded as shown in Table 3. Bacilliariophyceae was the most abundant group (43.47\%) followed by chlorophyceae (26.08\%) and Dinophyceae (7.8\%),respectively (Fig1).

Throughout the research, station 5 recorded the highest number of species (41) followed by station 3 (24), station 1 (20), station 4 (18) and station 2 (14) as shown in table 3.

Fig 2 shows the relationship between the physic-chemical parameters and sampling period. It can be observed that DO, BOD, water and air temperature were low in October. Table 4 and 5 
showed the correlation of the physic-chemical and heavy metals parameters respectively.

Table 1. The mean concentration for physico-chemical parameters measured monthly in Agaie- Lapai Dam.

\begin{tabular}{|c|c|c|c|c|c|c|c|}
\hline Parameters & $\begin{array}{c}\text { Mid } \\
\text { August }\end{array}$ & Aug ending & Mid Sept. & Sept. ending & Mid Otober & $\begin{array}{c}\text { October } \\
\text { ending }\end{array}$ & $\begin{array}{c}\text { C.V } \\
(\%)\end{array}$ \\
\hline $\begin{array}{c}\text { Total hardness } \\
(\mathrm{mg} / \mathrm{l})\end{array}$ & $54.4^{\mathrm{a}} \pm 11.7$ & $39.8^{\mathrm{a}} \pm 13.82$ & $41.6^{\mathrm{a}} \pm 6.22$ & $43.6^{\mathrm{a}} \pm 5.3$ & $50.8^{\mathrm{a}} \pm 6.09$ & $46.40^{\mathrm{a}} \pm 6.22$ & 12.2 \\
\hline Conductivity & $66.40^{\mathrm{b}} \pm 5.8$ & $116.6^{\mathrm{a}} \pm 53.9$ & $95.20^{\mathrm{ab}} \pm 4.0$ & $94^{\mathrm{ab}} \pm 4.0$ & $67.8^{\mathrm{b}} \pm 3.34$ & $89.60^{\mathrm{ab}} \pm 7.92$ & 21.40 \\
\hline $\begin{array}{c}\text { Dissolve } \\
\text { oxygen(mg/l) }\end{array}$ & $3.8^{\mathrm{ab}} \pm 1.17$ & $5.4^{\mathrm{a}} \pm 1.14$ & $4.4^{\mathrm{ab}} \pm 0.89$ & $5.12^{\mathrm{a}} \pm 1.25$ & $2.80^{\mathrm{b}} \pm 0.83$ & $4.60^{\mathrm{ab} \pm 0.54}$ & 21.8 \\
\hline $\begin{array}{c}\text { Biological } \\
\text { oxygen demand } \\
(\mathrm{mg} / \mathrm{l})\end{array}$ & $1.36^{\mathrm{a}} \pm 0.43$ & $3.20^{\mathrm{b}} \pm 1.09$ & $2.80^{\mathrm{ab}} \pm 1.09$ & $2.80^{\mathrm{ab}} \pm 01$ & $1.44^{\mathrm{a}} \pm 0.38$ & $3.20^{\mathrm{b}} \pm 0.83$ & 34.4 \\
\hline $\begin{array}{c}\text { Carbon(iv)oxide } \\
(\mathrm{mg} / \mathrm{l})\end{array}$ & $0.95^{\mathrm{ab}} \pm 0.3$ & $1.09^{\mathrm{abc}} \pm 0.88$ & $1.45^{\mathrm{c}} \pm 0.20$ & $1.43^{\mathrm{bc} \pm 0.21}$ & $0.91^{\mathrm{a}} \pm 0.27$ & $1.41^{\mathrm{c}} \pm 0.24$ & 20.7 \\
\hline $\begin{array}{c}\text { Air temperature } \\
\left({ }^{\circ} \mathrm{C}\right)\end{array}$ & $24.6^{\mathrm{b}} \pm 0.54$ & $25.6^{\mathrm{b}} \pm 0.54$ & $25.2^{\mathrm{a}} \pm 0.44$ & $29.00^{\mathrm{b}} \pm 1.00$ & $29.00^{\mathrm{b}} \pm 0.00$ & $25.20^{\mathrm{a}} \pm 0.44$ & 7.6 \\
\hline $\begin{array}{c}\text { Water } \\
\text { temperature }\left({ }^{\circ} \mathrm{C}\right)\end{array}$ & $21.20^{\mathrm{a}} \pm 1.0$ & $21.40^{\mathrm{a}} \pm 0.89$ & $22.20^{\mathrm{ab}} \pm 0.44$ & $25.00^{\mathrm{d}} \pm 0.00$ & $24.20^{\mathrm{cd}} \pm 0.44$ & $23.20^{\mathrm{bc}} \pm 1.30$ & 6.7 \\
\hline Alkalinity (mg/l) & $17.60^{\mathrm{a}} \pm 6.1$ & $15.60^{\mathrm{a}} \pm 5.54$ & $20.00^{\mathrm{a}} \pm 4.69$ & $17.20^{\mathrm{a}} \pm 2.28$ & $19.28^{\mathrm{a}} \pm 2.34$ & $19.40^{\mathrm{a}} \pm 2.19$ & 9.2 \\
\hline pH & $6.63^{\mathrm{ab}} \pm 0.2$ & $6.94^{\mathrm{a}} \pm 0.15$ & $6.60^{\mathrm{a}} \pm 0.18$ & $6.65^{\mathrm{ab}} \pm 0.09$ & $6.54^{\mathrm{a}} \pm 0.21$ & $6.74^{\mathrm{ab} \pm 0.17}$ & 2.10 \\
\hline Nitrate & $0.28^{\mathrm{a}} \pm 0.1$ & $0.26 \mathrm{a} \pm 0.03$ & $0.30^{\mathrm{a}} \pm 0.05$ & $0.27^{\mathrm{a}} \pm 0.03$ & $0.23^{\mathrm{a}} \pm 0.02$ & $0.28^{\mathrm{a}} \pm 0.06$ & 7.4 \\
\hline Phosphate (mg/l) & $0.04^{\mathrm{a}} \pm 0.01$ & $0.049^{\mathrm{a}} \pm 0.01$ & $0.04^{\mathrm{a}} \pm 0.01$ & $0.05^{\mathrm{a}} \pm 0.01$ & $0.05^{\mathrm{a}} \pm 0.00$ & $0.04^{\mathrm{a}} \pm 0.00$ & 11.1 \\
\hline
\end{tabular}

Means in the same row having same superscript are not significantly different from each other $(\mathrm{P}>0.05)$

Table 2. Heavy metals in Agaie-Lapai dam from August to October 2014.

\begin{tabular}{|l|l|l|l|l|l|l|l|}
\hline $\begin{array}{l}\text { Parameter } \\
(\mathrm{mg} / \mathrm{l})\end{array}$ & mid august & $\begin{array}{l}\text { august } \\
\text { ending }\end{array}$ & $\begin{array}{l}\text { mid } \\
\text { September }\end{array}$ & $\begin{array}{l}\text { september } \\
\text { ending }\end{array}$ & mid October & october ending & $\begin{array}{l}\text { C.V } \\
(\%)\end{array}$ \\
\hline zinc $(\mathrm{zn})$ & $0.03^{\mathrm{a}} \pm 0.01$ & $0.04^{\mathrm{a}} \pm 0.01$ & $0.05^{\mathrm{ab}} \pm 0.01$ & $0.05^{\mathrm{ab}} \pm 0.01$ & $0.09^{\mathrm{c}} \pm 0.02$ & $0.06^{\mathrm{bc}} \pm 0.02$ & 39.62 \\
\hline copper(cu) & $0.006^{\mathrm{a}} \pm 0.0$ & $0.004^{\mathrm{a}} \pm 0.005$ & $0.002^{\mathrm{a}} \pm 0.004$ & $0.004^{\mathrm{a}} \pm 0.005$ & $0.006^{\mathrm{a}} \pm 0.005$ & $0.012^{\mathrm{a}} \pm 0.017$ & 50.00 \\
\hline iron $(\mathrm{fe}))$ & $0.31^{\mathrm{a}} \pm 0.03$ & $0.36^{\mathrm{a}} \pm 0.04$ & $0.36^{\mathrm{a}} \pm 0.00$ & $0.26^{\mathrm{a}} \pm 0.05$ & $0.30^{\mathrm{a}} \pm 0.04$ & $0.28^{\mathrm{a}} \pm 0.08$ & 12.90 \\
\hline lead $(\mathrm{pb})$ & $0.00 \pm 0.00$ & $0.00 \pm 0.00$ & $0.00 \pm 0.00$ & $0.00 \pm 0.00$ & $0.00 \pm 0.00$ & $0.00 \pm 0.00$ & 0.00 \\
\hline Manganese(Mn) & & $0.01^{\mathrm{ab}} \pm 0.00$ & $0.03^{\mathrm{bcd}} \pm 0.01$ & $0.01^{\mathrm{a}} \pm 0.00$ & $0.04^{\mathrm{d}} \pm 0.01$ & $0.03^{\mathrm{cd}} \pm 0.01$ & 51.17 \\
\hline
\end{tabular}


$0.02^{\mathrm{abc}} \pm 0.0$

Means in the same row having same superscript are not significantly different from each other $(\mathrm{P}>0.05)$

Table 3. Percentage Relative abundance of phytoplankton Species in Agaie - Lapai Dam

\begin{tabular}{|c|c|c|c|c|c|c|c|c|c|c|c|c|}
\hline plankton group & species & $\mathrm{ST} 1$ & $\mathrm{R}(\%)$ & $\mathrm{ST} 2$ & $\mathrm{R}(\%)$ & $\mathrm{ST} 3$ & $\mathrm{R}(\%)$ & $\mathrm{ST} 4$ & $\mathrm{R}(\%)$ & $\mathrm{ST} 5$ & $\mathrm{R}(\%)$ & $\mathrm{C} . \mathrm{V}(\%)$ \\
\hline Bacillariophyceae & Navicula sp. & 6 & 30 & 4 & 28.57 & 6 & 25.00 & 6 & 33.33 & 11 & 26.83 & 39.55 \\
\hline & Asterionellasp & 1 & 5 & 1 & 7.14 & 2 & 8.33 & 1 & 5.56 & 4 & 9.76 & 72.43 \\
\hline & Nitchiasp & 2 & 10 & 1 & 7.14 & 3 & 12.50 & 2 & 11.11 & 2 & 4.88 & 35.35 \\
\hline Chlorophyceae & Chlamidomonassp & 2 & 10 & 3 & 21.43 & 2 & 8.33 & 3 & 16.67 & 4 & 9.76 & 29.88 \\
\hline & Volvoxsp & 0 & 0 & 1 & 7.14 & 2 & 8.33 & 1 & 5.56 & 1 & 2.44 & 70.71 \\
\hline & Branchiomonassp & 1 & 5 & 0 & 0.00 & 1 & 4.17 & 1 & 5.56 & 2 & 4.88 & 136.93 \\
\hline & Spirosyrasp & 0 & 0 & 1 & 7.14 & 0 & 0.00 & 1 & 5.56 & 0 & 0.00 & 55.90 \\
\hline & Monostromasp & 1 & 5 & 1 & 7.14 & 1 & 4.17 & 0 & 0.00 & 1 & 2.44 & 108.32 \\
\hline Dinophyceae & ceratiumsp & 0 & 0 & 0 & 0.00 & 1 & 4.17 & 3 & 16.67 & 3 & 7.32 & 233.61 \\
\hline & Peridiniumsp & 0 & 0 & 0 & 0.00 & 0 & 0.00 & 0 & 0.00 & 2 & 4.88 & 136.93 \\
\hline Cyanophyceae & chroococcussp & 3 & 15 & 0 & 0.00 & 0 & 0.00 & 0 & 0.00 & 3 & 7.32 & 104.58 \\
\hline & Gloeocapsasp & 1 & 5 & 0 & 0.00 & 1 & 4.17 & 0 & 0.00 & 2 & 4.88 & 71.26 \\
\hline Chrysophyceae & uroglenasp & 2 & 10 & 1 & 7.14 & 2 & 8.33 & 0 & 0.00 & 3 & 7.32 & 83.85 \\
\hline & Dinobryonsp & 1 & 5 & 1 & 7.14 & 3 & 12.50 & 0 & 0.00 & 3 & 7.32 & 44.78 \\
\hline & TOTAL & 20 & 100 & 14 & 100 & 24 & 100 & 18 & 100. & 41 & 100 & \\
\hline
\end{tabular}

Table 4. Correlation showing the relationship between the physic-chemical parameters measured

\begin{tabular}{|c|c|c|c|c|c|c|c|c|c|c|}
\hline & $\begin{array}{l}\text { Total } \\
\text { hardness } \\
(\mathrm{mg} / \mathrm{l})\end{array}$ & $\begin{array}{l}\text { Con } \\
\text { duct } \\
\text { ivity }\end{array}$ & $\begin{array}{l}\text { Dissolve } \\
\text { oxygen( } \\
\mathrm{mg} / \mathrm{l})\end{array}$ & $\begin{array}{l}\text { Biological } \\
\text { oxygen } \\
\text { demand } \\
(\mathrm{mg} / \mathrm{l})\end{array}$ & $\begin{array}{l}\text { Carbon(i } \\
\text { v)oxide } \\
(\mathrm{mg} / \mathrm{l})\end{array}$ & $\begin{array}{l}\text { Air } \\
\text { temperat } \\
\text { ure }\left({ }^{\circ} \mathrm{C}\right)\end{array}$ & $\begin{array}{l}\text { Water } \\
\text { tempera } \\
\text { ture } \\
\left({ }^{\circ} \mathrm{C}\right)\end{array}$ & $\begin{array}{l}\text { Alkali } \\
\text { nity } \\
(\mathrm{mg} / \mathrm{l})\end{array}$ & $\begin{array}{l}\mathrm{p} \\
\mathrm{H}\end{array}$ & $\begin{array}{l}\mathrm{Ni} \\
\text { tra } \\
\text { te }\end{array}$ \\
\hline \multicolumn{11}{|l|}{$\begin{array}{l}\text { Total } \\
\text { hardness } \\
(\mathrm{mg} / \mathrm{l})\end{array}$} \\
\hline Conductivity & $\begin{array}{r}-0.94686 \\
\underline{2824} \\
\end{array}$ & & & & & & & & & \\
\hline $\begin{array}{l}\text { Dissolve } \\
\text { oxygen }(\mathrm{mg} / \mathrm{l} \\
\text { ) }\end{array}$ & $\begin{array}{r}-0.77511 \\
1823\end{array}$ & $\begin{array}{r}\frac{0.88}{094} \\
\frac{197}{6}\end{array}$ & & & & & & & & \\
\hline Biological & -0.87468 & $\underline{0.89}$ & 0.85745 & & & & & & & \\
\hline
\end{tabular}




\begin{tabular}{|c|c|c|c|c|c|c|c|c|c|c|}
\hline $\begin{array}{l}\text { oxygen } \\
\text { demand } \\
(\mathrm{mg} / \mathrm{l})\end{array}$ & 6109 & $\frac{158}{\frac{952}{5}}$ & 9822 & & & & & & & \\
\hline $\begin{array}{l}\text { Carbon(iv)o } \\
\text { xide (mg/l) }\end{array}$ & $\begin{array}{r}-0.61971 \\
9563\end{array}$ & $\begin{array}{r}0.48 \\
799 \\
973 \\
8\end{array}$ & $\begin{array}{r}0.59879 \\
5756\end{array}$ & $\underline{0.757475927}$ & & & & & & \\
\hline $\begin{array}{l}\text { Air } \\
\text { temperature } \\
\left({ }^{0} \mathrm{C}\right)\end{array}$ & $\begin{array}{r}0.015230 \\
941\end{array}$ & $\begin{array}{r}-0.1 \\
658 \\
778 \\
8\end{array}$ & $\frac{-0.23528}{\underline{807}}$ & -0.196981599 & $\begin{array}{r}-0.06748 \\
5622\end{array}$ & & & & & \\
\hline $\begin{array}{l}\text { Water } \\
\text { temperature } \\
\left({ }^{0} \mathrm{C}\right)\end{array}$ & $\begin{array}{r}-0.01299 \\
2498\end{array}$ & $\begin{array}{r}-0.1 \\
677 \\
777 \\
8\end{array}$ & $\begin{array}{r}-0.13731 \\
79\end{array}$ & 0.020512631 & $\begin{array}{r}0.302029 \\
244\end{array}$ & $\frac{0.877938}{\underline{533}}$ & & & & \\
\hline $\begin{array}{l}\text { Alkalinity } \\
(\mathrm{mg} / \mathrm{l})\end{array}$ & $\begin{array}{r}0.239771 \\
563\end{array}$ & $\begin{array}{r}-0.4 \\
709 \\
647 \\
9\end{array}$ & $\frac{-0.56400}{\underline{031}}$ & -0.170482145 & $\begin{array}{r}0.282671 \\
314\end{array}$ & $\begin{array}{r}-0.01355 \\
0875\end{array}$ & $\begin{array}{r}0.25849 \\
1897\end{array}$ & & & \\
\hline $\mathrm{pH}$ & $\begin{array}{r}-0.56788 \\
4167 \\
\end{array}$ & $\begin{array}{r}\frac{0.79}{\underline{770}} \\
\frac{655}{2} \\
\end{array}$ & $\begin{array}{r}0.75421 \\
6385\end{array}$ & 0.662181816 & $\begin{array}{r}0.056307 \\
029\end{array}$ & $\begin{array}{r}-0.37591 \\
2701\end{array}$ & $\begin{array}{r}-0.4361 \\
7121\end{array}$ & $\begin{array}{r}-0.707 \\
94\end{array}$ & & \\
\hline Nitrate & $\begin{array}{r} \\
-0.26221 \\
7153\end{array}$ & $\begin{array}{r}0.24 \\
081 \\
549 \\
6\end{array}$ & $\begin{array}{r}0.44716 \\
1132\end{array}$ & 0.399714439 & $\begin{array}{r}0.663617 \\
978\end{array}$ & $\frac{-0.67994}{4427}$ & $\begin{array}{r}-0.3958 \\
8336\end{array}$ & $\begin{array}{r}0.2164 \\
51\end{array}$ & $\begin{array}{r}0 . \\
04 \\
17 \\
2\end{array}$ & \\
\hline $\begin{array}{l}\text { Phosphate } \\
(\mathrm{mg} / \mathrm{l})\end{array}$ & $\begin{array}{r}-0.23316 \\
7282\end{array}$ & $\begin{array}{r}0.21 \\
488 \\
678 \\
5\end{array}$ & $\begin{array}{r}0.06194 \\
1967\end{array}$ & -0.01485234 & $\begin{array}{r}-0.26650 \\
893\end{array}$ & $\frac{0.820331}{122}$ & $\begin{array}{r}0.52629 \\
065\end{array}$ & $\begin{array}{r}-0.496 \\
55\end{array}$ & $\begin{array}{c}0 . \\
14 \\
44\end{array}$ & $\begin{array}{r}-0 \\
.7 \\
80 \\
3\end{array}$ \\
\hline
\end{tabular}

Table 5. Correlation showing relationship between the heavy metals measured

\begin{tabular}{|l|c|l|l|l|}
\hline & zinc (zn) & copper(cu) & iron (fe) $)$ & lead (pb) \\
\hline zinc (zn) & & & & \\
\hline copper(cu) & $\underline{0.2435978}$ & & & \\
\hline iron (fe) $)$ & -0.2899131 & $\underline{-0.5309145}$ & & \\
\hline lead (pb) & 0 & 0 & 0 & \\
\hline Manganese(Mn) & $\underline{0.74620251}$ & 0.3196014 & -0.0133643 & 0 \\
\hline
\end{tabular}




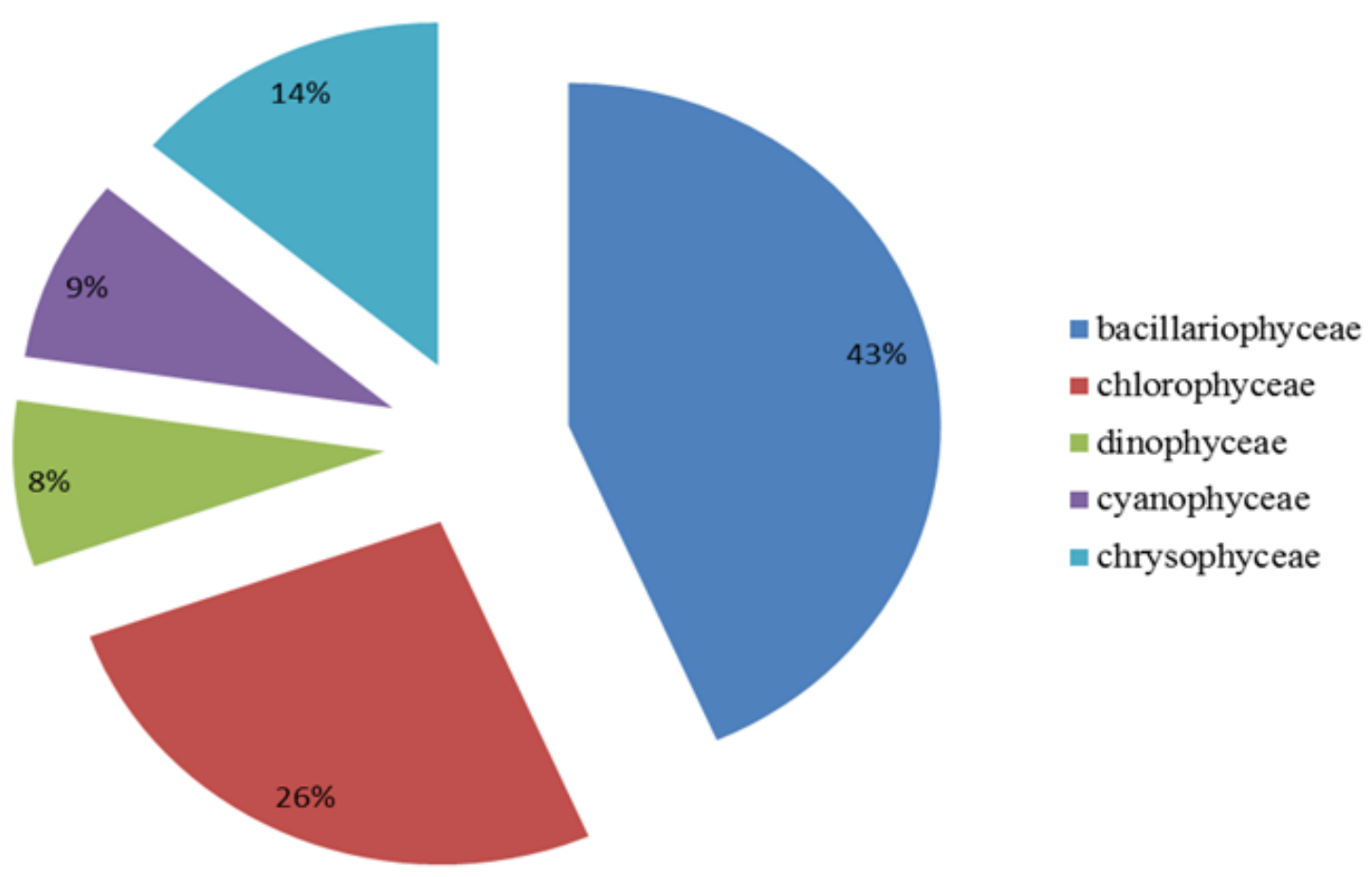

Fig. 1. Phytoplankton Abundance in Agaie-Lapai Dam from August to October, 2014.

The research shows that there were 14 different species of phytoplankton belonging to 5 different families identified in the reservoir of Agaie-Lapai Dam.

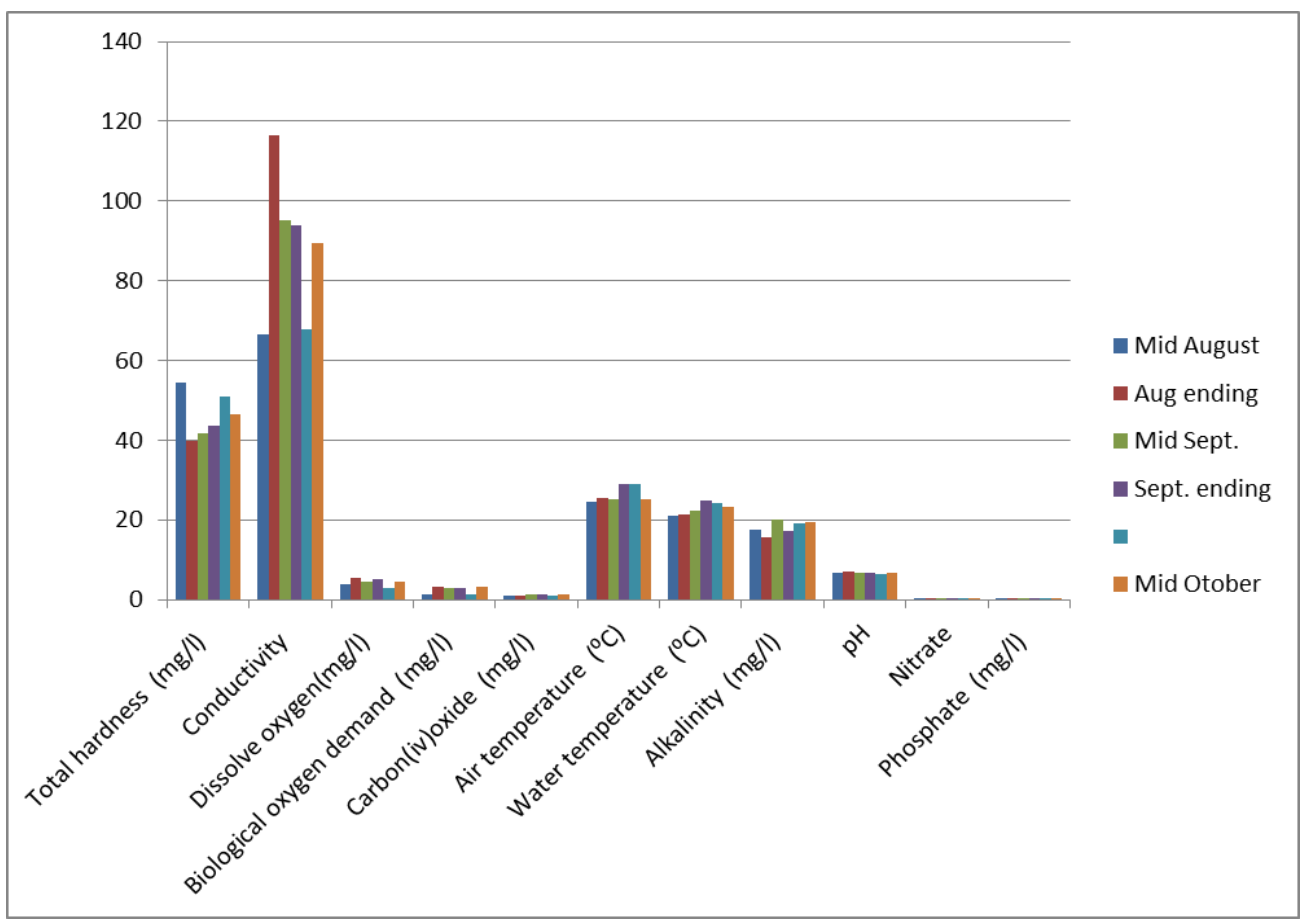

Fig 2. Graphical relationship between the parameters and the sampling period 


\section{Discussion}

The study was carried out to assess the phytoplankton abundance, heavy metal concentration and physico-chemical parameters of Agaie - Lapai dam in order to ascertain the status of the dam.

The air and water temperature recorded fell within the range of $21^{\circ} \mathrm{C}$ and $29^{\circ} \mathrm{C}$. This range compares with other tropical water bodies (Kolo and Oladimeji, 2004).Boyd and Frobish (1990) also observed that in tropical climates, water temperatures are high all the year round; nevertheless, differences in air temperature between raining and dry seasons may appreciably affect water temperature. Both air and water temperature range falls within recommended value for aquaculture as reported by Dupree and Hunner (1984) who observed that warm water fish grow best at temperatures of between $25^{\circ} \mathrm{C}$ and $32^{\circ} \mathrm{C}$.

The mean value of dissolved oxygen recorded in cold rainy season compared to warm dry season could be due to much agitation and influx of water. The $6 \mathrm{mg} / \mathrm{l}$ dissolved oxygen recorded in some months during the study period agrees with recommendations of some researchers that said most biologists accept $6 \mathrm{ppm}$ as the minimum concentration of the dissolved oxygen requirements for fish (Tukura, 2002).

The research shows that hardness ranges between $39.8 \mathrm{mg} / \mathrm{l}$ and $54.4 \mathrm{mg} / \mathrm{l}$.

The $\mathrm{pH}$ range recorded for this study falls within the recommended range $6.5-7.5$ that will support aquatic life including fish (Boyd, 1979).Applying the classification of Thurston et al. (1979), of $0-75 \mathrm{mg} / \mathrm{l} \mathrm{CaCO}_{3}$ hardness is termed as soft water and $75-150 \mathrm{mg} / \mathrm{l}$ to moderately hard water, it can be concluded that the water of Agaie - Lapai dam generally soft, however, hard water is known to be more productive than soft water.

The higher BOD recorded could be as a result of organic materials like wood and debris. This could also be due to woody area of the dam, therefore organic matter decay process used up the dissolved oxygen, thus resulting in lower dissolved Oxygen content and high BOD. Imevbore (1975) and Obioha (1984) observed similar effects in Eleyelereservior in Ibadan.

Nitrate-nitrogen recorded was generally low during the study. This could be attributed to decreased farming activities in the area. Nitrate and phosphate requirement by phytoplankton is ratio 10:1 (N: P) by weight (Stirling and Philips, 1990) with phosphate being regarded as the most limiting factor in most natural freshwaters.

The range observed during this study suggests that the river has no greater primary production potentials in terms of nitrate concentration compared to Lake Asejire in Nigeria (Egborge, 1979). All the physico-chemical parameters fall within the acceptable limit that was allowed by WHO (1991). Some of these physic-chemical parameters showed positive correlation while some were negative during the sampling period.

The low level of heavy metals shows that the water is in a tolerable limit for aquatic 
organisms, no visible form of pollution and thus, make it productive.

The results obtained from the physiochemical parameters were within tolerable limits for aquatic life which could also be responsible for the diversity of the species recorded in the dam. This agrees with findings of Edward and Ugwunba, 2010. There is no visible form of pollution of the water.

The result obtained compared favourably with some Nigerian reservoir waters. Tolani (2011) observed 13 species belonging to 4 different taxonomic groups. Chlophyceae was most abundant closely followed by bacillariophyceae. The water quality was not significantly different from each other.

This result however varied considerably with Edward and Ugwunba (2004) who identified 35 genera of phytoplankton and diatoms being evenly distributed in Egbe reservoir, Ekiti state, Nigeria. The distribution of bacillariophyceae agrees with the report of Aneni and Hassan (2003) that shows great diversity and equitability in Onireke and Kudati stream, Ibadan.

The research shows that phytoplankton abundance is in the following decreasing order: Bacillariophyceae $>$ Chlorophyceae $>$ Chrysophyceae $>$ Cyanophyceae $>$ Dinophyceae. This order of phytoplankton abundance observed is not too different from report of that of Chindah (2003)

which

is

Bacillariophyceae $>$ Cyanophyceae $>$ Chloropyhceae, $>$ Euplenophyceae $>$ Dinophycea.

\section{Conclusion}

The result revealed that there were only few species (Naviculasp, Asterionellasp, Nitchiasp, Chlamidomonassp, Volvoxsp, Branchiomonassp, Spirosyrasp, Monostromasp, Ceratiumsp, Peridiniumsp, Chroococcussp, Gloeocapsasp, Uroglenasp, Dinobryonsp) of phytoplankton present in this dam and they are not evenly distributed throughout the water. This could actually support the growth and sustainability of some species fish in this Dam.

\section{References}

Apha (2005). Standard methods for the examination of water and waste water 18th edition, American Public Health Association, Washington.

Abowei, J. F. N, Ezekiel E. N., \& Hensen U. (2012). Effects of water pollution of phytoplankton, Species composition in Koluama area, Niger Delta area Nigeria.

Aneni, I. T, \& Hassan A. T. (2003). Effect of pollution on seasonal abundance of plankton in Kudetiandonireke stream, Ibadan, Nigeria. The Zoologist, 2(2), 76-83.

Boyd, C. E. (1979). Water quality for warm fish ponds. Auburn University Agricultural Experimental station, 359pp.

Boyd, C. E., \& Frobish, L. T. (1990). Water quality in ponds for aquaculture, Birmingham publishing Co, Birmingham, Alabama.

Boyd, C. E., \& Tucker C. S. (1992). Water quality Pond Soil analysis for aquaculture.Alabama, Agricultural Experiment Station, Auburn University, Alabama, 183pp. 


\section{Macrothink}

Journal of Biology and Life Science ISSN 2157-6076 2016, Vol. 7, No. 2

Casey, C. B. (2009). Tidal influences on bacteria and phytoplankton abundances and the resulting effects on patterns of dissolved oxygen in the tidaway River Estuary. Georgia Southern, University.

Chindah, A. C. (2003). The physiochemistry phytoplankton of a swamp forest stream in the lower Niger Delta. Scentia Africa. L, (2), 1-15

Dimowo, B. O. (2013). Monthly Spatial Occurrence of Phytoplankton and Zooplankton in River Ogun, Abeokuta, Ogun State, Southwest Nigeria. International journal of fisheries and Aquaculture. 5(8), 193-203.

Dupree, H. A., \& Hunner, J. U. (1984). The status of warm water fish farming and progress in fish farming research. U.S fish and wild life service, Washington D.C, U.S.A pp 155.

Edward, J. B., \& Ugwumba A. A. A. (2010). Physiochemical parameters and plankton community of egbe reservoir, Ekiti State Nigeria. International journal of biological chemistry. 12, 4-9

Egborge, A. B. M. (1979). Observation of the vertical distribution of the zooplankton in the Lake Asejire new impoundment. Proceedings, International conference, Kainji and River basin development in Africa, Ibadan. 11-17 December 1977, 208-218.

Imevbore, A. M. A. (1975). The chemistry of River Niger in the Kainji reservoir area. 67(3), 413, 404-426.

Kolo, R. J., \& Oladimeji, A. A. (2004). Water quality and some nutrient level in Shiroro Lake, Niger State, Nigeria. Journal of Aquatic Sciences 19(2), 99-106.

Lee I. K. (1999). Monitoring of Algae bloom at Seomjin River Estuarine, Southern Coast of Korea. Algae. 18(4), 361-363

Maristela, C. Enide, E. Sigrid, N. L., Eneida, E. S. A., Ralf, S., Antonia, T. de Moraes Junior. (2003). Plankton community as an indicator of water quality in tropical shrimp culture ponds. Marine pollution bulletine, 56, 1343-1352

Obioha, A. (1984). Studies of the water quality and plankton periodicity in two contrasting mine Lakes in Jos Plateau. M.Sc thesisis, University of Jos, Nigeria 122pp

Onyema, I. C. (2003). Thephyloplankton composition abundance and temporal variation of a polluted estuarine Creek in Lagos, Nigeria. Turkish Journal of Fisheries and Aquatic Sciences, 7, 89-96.

Palleyi, S. Kar, R. N, Panda, C. R. (2011). Influence of water quality on the biodiversity of phytoplankton in Ohamrariver Estuary of Odisha Coast, Bay of Bengal. Journal of environmental biology, 67, 234-238.

Stirling, H. P., \& Phillips, M. J. (1990). Water quality management for aquaculture and Fisheries Edited by Bangladesh Aquaculture and Fisheries Resource Unit (BAFRU). Institute of Aquaculture, University of Stirling, Scotland U.K. 49pp. 


\section{Macrothink}

Journal of Biology and Life Science ISSN 2157-6076 2016, Vol. 7, No. 2

Tolani, U. M. (2011). Biodiversity of phytoplankton in Agaie-Dam Niger State, Nigeria. Federal university of technology, minna, Nigeria.

WHO. (1991). International standards for drinking water: $3^{\text {rd }}$ Ed. Word Health Organization Organization, Geneva.

\section{Copyright Disclaimer}

Copyright for this article is retained by the author(s), with first publication rights granted to the journal.

This is an open-access article distributed under the terms and conditions of the Creative Commons Attribution license (http://creativecommons.org/licenses/by/3.0/). 